Publicación semestral. ISSN 2215-4906

Volumen 79 - Número 2

Enero - Junio 2020

\title{
Hacia un nuevo ideal femenino: el pianismo decimonónico de Guadalupe Olmedo y María Garfias
}

\section{Toward a New ldeal of the Feminine: the Nineteenth-Century Pianism of Guadalupe Olmedo and María Garfias}

Alejandro Barrañón

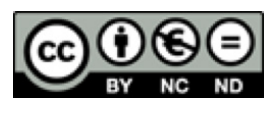

Esta obra está bajo una licencia Creative Commons Reconocimiento-No comercial-Sin Obra Derivada 
Dossier

\title{
Hacia un nuevo ideal femenino: el pianismo decimonónico de Guadalupe Olmedo y María Garfias
}

\section{Toward a New Ideal of the Feminine: the Nineteenth-Century Pianism of Guadalupe Olmedo and María Garfias}

\author{
Alejandro Barrañón ${ }^{1}$ \\ Universidad Autónoma de Zacatecas \\ México
}

Recibido: 30 de marzo de 2019 Aprobado: 05 de julio de 2019

\begin{abstract}
Resumen
En este artículo se hacen comentarios analíticos y contextuales de una selección de obras pianísticas de las compositoras mexicanas Guadalupe Olmedo (1856-1889) y María Garfias (1849-1918) y se muestran paralelismos y diferencias en el discurso musical y el pianismo de ambas. Las partituras aquí comentadas, encontradas en diversos archivos institucionales y privados de México, conforman un repertorio hasta ahora poco abordado que refleja las primeras obras de concierto compuestas por mujeres mexicanas. Garfias estudió con reconocidos maestros y Olmedo, formada profesionalmente en el Conservatorio Nacional de México, fue la primera mujer graduada de la carrera de composición. Las propuestas de ambas fueron audaces: concibieron y plasmaron obras de gran virtuosismo y se apartaron del ideal femenino convencionalmente aceptado en el México decimonónico.
\end{abstract}

Palabras clave: mujeres compositoras; interpretación musical; musicología; música del siglo XIX en México; repertorio pianístico

1 Docente investigador de la Universidad Autónoma de Zacatecas; concertista del Instituto Nacional de Bellas Artes y Literatura de México. Doctor of Musical Arts por la University of Houston. Correo electrónico: abarranon@yahoo.com

ESCENA. Revista de las artes, 2019, Vol. 79, Núm. 1, pp. 189-213 ISSN 2215-4906 


\begin{abstract}
The article presents analytical and contextual commentaries upon a selection of piano pieces composed by Guadalupe Olmedo (1856-1889) and María Garfias (1849-1918), showing similarities and differences between their respective musical aesthetics. The scores of these pieces were found at different archives in institutions in Mexico, as well as in private collections. This repertoire has been seldom performed and shows the first concert-pieces composed by Mexican women in the Nineteenth century. Garfias studied with well-known Mexican composers and Olmedo was the first woman ever to graduate in composition at Mexico's National Conservatory. Both composers proposed an innovative musical language: they wrote virtuoso piano pieces that stood out on account of their boldness, originality and risk-taking musical language which contradicted the feminine ideal of this period.
\end{abstract}

Keywords: Women composers; musical performance; musicology; 19th century music in México; musical repertoire

ESCENA. Revista de las artes, 2020, Vol. 79, Núm. 2 (enero-junio), pp.189-213 
Hacia un nuevo ideal femenino: el pianismo decimonónico de Guadalupe

Dossier Olmedo y María Garfias

\section{Introducción}

El presente ensayo aborda la producción pianística de las compositoras Guadalupe Olmedo Lama (1856-1889) y María Garfias (1849-1918) de acuerdo con una recopilación de obras que realicé recientemente en diversos archivos de México, tales como el Archivo Histórico de la Biblioteca del Conservatorio Nacional de Música y la Biblioteca del Centro Nacional de las Artes y la colección privada del guitarrista Jorge Martín Valencia. Recabar información sobre estas compositoras ha sido un asunto complicado y casi estéril; hasta el momento no se han encontrado ni imágenes ni retratos de ellas, solo ocasionales referencias hemerográficas y, en el caso de Olmedo, un total de veinte partituras que sobreviven en manuscrito y otras más que fueron publicadas en México, Italia y Alemania. A pesar de haber sido la primera mujer graduada en el Conservatorio de México en la carrera de composición, en el texto conmemorativo escrito al final de su vida por el reconocido compositor Melesio Morales, quien fue su esposo y maestro, se omitió su nombre en una lista de veintitrés mujeres que asistieron a sus cursos de piano y composición². En lo que respecta a María Garfias, he podido encontrar las partituras de diecisiete obras para piano y tres canciones con acompañamiento pianístico, publicadas por el taller de imprenta de J. Rivera e hijo, y una obra publicada por Manuel Murguía.

Se pueden detectar en ambas compositoras diversos paralelismos: (a) recibieron su formación musical de personalidades del México decimonónico, algunas de las cuales estuvieron adscritas al Conservatorio Nacional; (b) tanto Garfias como Olmedo desarrollaron una fugaz carrera como destacadas pianistas en las que abordaron e interpretaron públicamente complicadas obras de Franz Liszt; (c) ambas, hasta antes de contraer matrimonio, compusieron obras de singular belleza en las que exploraron recursos compositivos innovadores, como las modulaciones de tipo enarmónico, por ejemplo, y (d) las dos declinaron su carrera artística en favor de la vida familiar. Una última coincidencia es que los restos mortales de estas compositoras reposan en el Panteón Español de la Ciudad de México; en el caso de Olmedo, en el mausoleo no aparece su nombre, solo se lee "Familia de Melesio Morales, 1889", y en el de Garfias, la inscripción reza: "Su hija política y nietas a Ma. G. de Garfias, 1918".

Durante gran parte del siglo XX, en México se tuvo la percepción de que en el siglo XIX las mujeres tuvieron una participación poco significativa en el área de la creación musical. No hace mucho, en 1958, la investigadora Esperanza Pulido, pionera en estudios sobre mujeres compositoras en México, comentó que "en lo concerniente a la creación musical ha sido nula la intervención de la mujer mexicana" (Pulido, 1991, p. 21). Sin embargo, en las últimas décadas se han encontrado partituras de mujeres mexicanas, como Delfina

2 Las únicas compositoras que reconoció Morales como graduadas de la carrera de composición son: Josefina Velasco, María Ramerí y María Vergara (Morales, 1906).

ESCENA. Revista de las artes, 2020, Vol. 79, Núm. 2 (enero-junio), pp. 189-213 
Mancera, Ángela Peralta, María Garfias y Guadalupe Olmedo, cuya actividad musical rebasó el ámbito familiar y destacaron públicamente como compositoras. Su audaz creatividad surgió en un momento de profundos cambios en los ámbitos de la política y la educación que transformaron el entorno cultural del México del siglo XIX, procesos en los que las mujeres desempeñaron un papel decisivo.

En este ensayo haré referencia, en primer término, a la educación musical de las mujeres mexicanas de generaciones anteriores a la de Olmedo. Después, hablaré de los nuevos espacios e instituciones que surgieron en el México independiente en los que las mujeres, desde el campo de la música, participaron activamente en los profundos cuestionamientos y posteriores cambios en los paradigmas del pensamiento y la educación de la sociedad mexicana decimonónica. Por último, haré un esbozo biográfico de las compositoras y me referiré a un grupo de obras pianísticas que revelan un lenguaje musical que gradualmente fue enriqueciéndose con audaces recursos compositivos, desde el cuidadoso equilibrio formal y la simplicidad de las primeras obras, hasta la desbordante ornamentación, el virtuosismo y el audaz planteamiento armónico de la Paráfrasis de Ildegonda de Olmedo y de la Bacanal de Garfias.

\section{Antecedentes}

Antes del siglo XIX, es prácticamente imposible hablar de compositoras mexicanas. En la época colonial, Fray Pedro de Gante fundó la primera escuela de música europea en el continente americano, destinada exclusivamente a jóvenes varones. Aun cuando no tengamos ninguna evidencia de que hubiera habido alguna compositora en México antes del siglo XIX, sabemos que la ilustre poeta Sor Juana Inés de la Cruz dedicó parte de su tiempo al estudio de la música, tanto en los aspectos de carácter especulativo como del práctico. En uno de sus romances, Sor Juana revela un profundo conocimiento de aspectos de teoría musica|3: la ilustre religiosa se refiere a las proporciones, la enarmonía, la música práctica y la música como "cognición intelectiva"; en los versos finales señala que escribió un tratado de música, desafortunadamente extraviado hasta hoy, "para ver si reducía a mayor facilidad las reglas que andan escritas" (Juana Inés de la Cruz, 1951).

En el siglo XVIII, se fundaron diversos colegios para mujeres en diferentes ciudades del país, en los que se incluyó la música como parte de la educación; por ejemplo, entre

3 Esperanza Pulido afirma que el afán de conocimientos musicales llevó a Sor Juana a estudiar a Pietro Cerone (1566-1616), músico napolitano que sirvió a Felipe II en España de 1592 a 1608. La obra de Cerone que llamó la atención de Sor Juana fue El melopeo y maestro, publicada en Nápoles en 1613, pero escrita en castellano, de la que se conserva un ejemplar con anotaciones de la preclara religiosa (cit. en Pulido, 1991, p. 21).

ESCENA. Revista de las artes, 2020, Vol. 79, Núm. 2 (enero-junio), pp.189-213 
1743 y 1746 en Valladolid, hoy Morelia, el Colegio de Santa Rosa de Santa María, conocido como el Conservatorio de las Rositas, institución en la que existía una escoleta de música diaria ${ }^{4}$ y en la Ciudad de México, el Colegio de San Miguel de Bethlén, que se ocupó de la enseñanza musical para mujeres, desde 1740 hasta 1821.

A mediados del siglo XIX, la mayoría de mujeres de clase acomodada cumplía diversos roles característicos del género femenino, orientados a asumir los papeles de madres y esposas y, con ello, garantizar las buenas costumbres, la estabilidad y la educación familiar para su descendencia. En aquel entonces no se pensaba que las mujeres pudieran destacar en otros ámbitos, como la ciencia, la política o la cultura. A lo largo del siglo XIX el sistema educativo mexicano diferenció las áreas de conocimiento dirigidas a hombres y a mujeres, lo cual marginaba a las segundas del estudio de las leyes y las ciencias, entre otras actividades, y no fue sino hasta 1889 cuando, como resultado de la primera conferencia pedagógica nacional, dicho sistema se uniformó para hombres y mujeres en el nivel elemental de educación (Aguirre Loera, 2002).

La investigadora Yael Bitrán (2012) ${ }^{5}$ refiere que a mediados del siglo XIX había por lo menos seis revistas dirigidas a ese sector del público; en ellas, además de publicar artículos de temas diversos, se incluían partituras de manera periódica para el solaz de las lectoras. Los títulos de cinco de esas revistas son: El Mosaico Mexicano (1840), Semanario de las Señoritas (1841), Panorama de las Señoritas (1842), El Museo Mexicano o Miscelánea Pintoresca (1843-1844) y Presente amistoso dedicado a las señoritas mexicanas, de Ignacio Cumplido (1847, 1850 y 1851). En este último, Cumplido recomienda en su artículo "Consejos a las señoritas":

Formado el carácter moral de una señorita con la religión y la virtud, debe adornar su entendimiento con algunos conocimientos, que aun cuando no sean profundos, sean útiles. Debe huir de dos extremos igualmente desagradables, y son, el de una ignorancia grosera, y el de una vana ostentación de su saber... Un aire de superioridad o de altanería, es el que peor sienta a una mujer (citado en Bitrán, 2012, pp. 75-76).

4 Miguel Bernal Jiménez encontró documentación relacionada con los requisitos de ingreso al Colegio de Santa Rosa: "la solicitud era dirigida directamente al obispo y acompañada de una información referente a la legitimidad y pureza de sangre de las candidatas quienes tenían que probar encontrarse sin mácula de mulatos, lobos, judíos, sambaígos, chinos, ni de los recién convertidos u otra mala raza, ni de penitenciados ni castigados por tribunal alguno... Las rositas estudiaban solfeo, canto coral religioso y profano, violín, arpa y quizá, clavicordio" (cit. en Pulido, 1991, pp. 25-26).

5 Una de las fuentes más importantes para el conocimiento de la participación femenina en la música de este período es la tesis doctoral de la investigadora Yael Bitrán (2012).

ESCENA. Revista de las artes, 2020, Vol. 79, Núm. 2 (enero-junio), pp. 189-213 
Más adelante, cuando Cumplido se refiere a las características que debe mostrar una joven pianista señala:

la receta es evitar todo tipo de pretensiones y actuar con "suprema simplicidad”, tocar con claridad, limpieza y expresividad. La música es valiosa por las impresiones que provoca en nuestra alma y no por sonidos estrepitosos o la complicación de su ejecución (citado en Bitrán, 2012, p. 76).

Si bien la mayoría de estas publicaciones promovían una postura conservadora en la forma de concebir los alcances de las aportaciones de la mujer en áreas consideradas reservadas al hombre, tanto el Panorama de las Señoritas como el Semanario de las Señoritas "unique within the Mexican print spectrum in its determined advocacy for better education and equality of opportunities for women [se distinguieron por su decidida defensa de una mejor educación e igualdad de oportunidades para la mujer]" (Bitrán, 2012, pp. 38-39), de manera que estas publicaciones fungieron como vasos comunicantes de nuevas y radicales ideas. Por otro lado, es importante subrayar que, en sus 470 páginas, el Semanario de las señoritas publicó diversos artículos sobre arte, cultura y conocimientos científicos, tratados de manera detallada y amena.

Bitrán describe que las mujeres jóvenes de familias acomodadas, desde finales del siglo XVIII y durante todo el siglo XIX, pudieron obtener sus conocimientos y habilidades

Figura 1. Portada del Panorama de las Señoritas

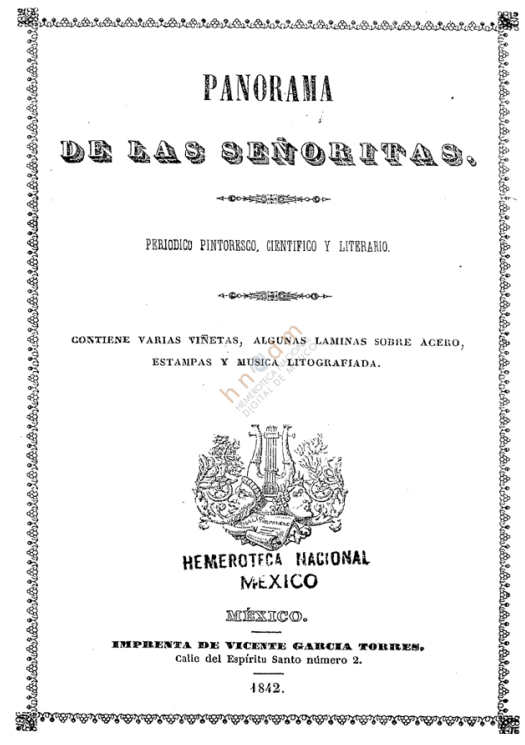

Fuente: Hemeroteca Nacional Digital de México. en idiomas, pintura, dibujo, baile y música por medio de maestros particulares en calidad de institutores y preceptores, y también mediante publicaciones dirigidas al público femenino. Todo un entramado de elementos se concatenaba en la intensa actividad musical de las mujeres de las clases acomodadas de México. Ellas hicieron que sus familias invirtieran en servicios y artículos relacionados con la música: clases particulares de piano con músicos profesionales nacionales o extranjeros, partituras, revistas y publicaciones, pianos y otros instrumentos musicales importados de Europa o construidos en el país, y por último, aunque no menos importante, fueron las mujeres, asistentes entusiastas a la ópera, quienes impulsaron la presencia cada vez más frecuente y arrolladora de la ópera italiana en los teatros mexicanos (Bitrán, 2012). La música se constituyó así en una disciplina en la que las mujeres, trascendiendo los límites de una formación doméstica y amateur, alcanzaron, en casos como los de Olmedo, Garfias y otras compositoras, un desarrollo de nivel superior. 
La fundación del Conservatorio en 1866 permitió por primera vez en México la formación profesional de hombres y mujeres. Hasta donde hemos indagado, fue la música la primera disciplina-precediendo incluso a la educación y la medicina- en la que se graduaron las primeras mujeres profesionistas de México, y fue precisamente Guadalupe Olmedo la primera mujer en lograrlo en la carrera de composición. Si bien María Garfias no fue alumna del Conservatorio, su formación estuvo dirigida por músicos adscritos a esta institución, como Agustín Balderas, y por otros no conservatorianos de reconocido prestigio, como Cenobio Paniagua y Octaviano Valle. Para comprender el alcance de las aportaciones de nuestras compositoras es necesario destacar algunos rasgos del pianismo mexicano del siglo XIX. Los compositores mexicanos de este período raramente compusieron sonatas, sinfonías, rondós y otras formas de diseños más o menos preestablecidos. El panorama pianístico-musical del siglo XIX en México, no obstante su cercanía con los modelos europeos en los que abreva, refleja un proceso de construcción de la identidad nacional, mediante una remodelación:

The Mexican bourgeoisie was in the process of constructing a national identity by refashioning: rejecting, resisting, adapting, inventing European ideas and practices and by searching their own background, historical, cultural and present, including their conflicted relation with the European powers ... [the] liberal and conservative parties debated, among other issues, the nature of important issues such as religion, the best government system for the country, the role of women, and education [La burguesía mexicana estaba en el proceso de construir una identidad nacional mediante una remodelación: rechazando, resistiendo, adaptando, inventando ideas y prácticas europeas, e investigando sus propios orígenes, históricos, culturales y presentes, incluyendo su relación conflictiva con los poderes europeos... Los partidos liberal y conservador debatían, entre otros asuntos, la naturaleza de importantes tópicos, tales como la religión, el mejor sistema de gobierno para el país, el papel de las mujeres y la educación] (Bitrán 2012, p. 21).

Hacia 1905, el compositor Melesio Morales, que había estudiado en Florencia, Italia, con uno de los primeros impulsores de la música de Wagner, Teódulo Mabellini, señalaba:

cuánto mejor sería que nuestros maestros dedicaran sus talentos y energías a la creación de un arte patrio, propio, característico, adecuado a nuestro particular modo de ser en relación directa con nuestros gustos, los que, por más que se predique, no han sido, ni son ni serán iguales a los de los austeros germanos, por más bellos que se pretendan (Morales, 1994, p. 149).

${ }^{6}$ No obstante esta postura suya, el propio Melesio Morales experimenta con obras intensamente cromáticas en las que recorre una gran variedad de tonalidades, como su Preludio y Fuga para piano, recurso ampliamente utilizado en Europa por aquel entonces. 
Además, Morales se refiere despectivamente a composiciones que, en su oponión, están "basadas en el narcótico desarrollo temático-sinfónico del discurso musical" y hace un llamado a

prescindir de la mala mafia de plantarse frente a frente de la escuela alemana, a respirar su fría atmósfera... las condiciones climatológicas de nuestra tierra no favorecen la inmigración de ese arte severo, docto y monumental, es verdad, pero glacial, desabrido, que no prospera al intenso calor de nuestro ardiente sol (Morales, 1994, pp. 148-149).

Con este espíritu, a mediados del siglo XIX surgen en México obras en las que se observa una asimilación de la música europea a la que se añaden rasgos de la música local. Salen a la luz, los Ecos de México de Ituarte, las Variaciones sobre el Jarabe de José Antonio Gómez con temas de la música popular criolla, así como óperas con temas del México antiguo, como Guatimotzin de Aniceto Ortega. Por su parte, las obras de Olmedo y Garfias reflejan en cierta manera los ideales de Morales; predomina el discurso musical cercano al bel canto, y posteriormente, como en la Paráfrasis de Ildegonda, y en la Obertura Republicana de Garfias, el virtuosismo de tipo lisztiano. Encontramos, además, en la Fantasía Martha de Garfias, recursos compositivos cercanos al tema y variación que desarrolló Henri Herz, pianista austriaco que vivió en México durante siete meses a mediados de dicho siglo.

\section{Apuntes biográficos}

Las referencias biográficas que hemos encontrado de estas compositoras nos brindan valiosa información tanto para el caso de Olmedo como para Garfias, como exponemos a continuación?

El verdadero nombre de María Garfias (1849-1918) fue María Rita de la Preciosa Sangre García Garfias, cuya fugaz carrera duró apenas seis años, de 1862 a 1868. De acuerdo a la información que disponemos de ella podemos afirmar que poseía un pianismo superior, lo que llevó al compositor y diplomático venezolano Dr. Felipe Larrazábal a expresar que quería ver sus manos para comprobar si "eran divinas o humanas" (Carrasco, 2018, p. 24). Nacida el 22 de mayo de 1849 en la Ciudad de México, sus padres fueron: José García Garfias y María del Refugio Malabear. Sus primeras lecciones las tomó con la pianista Refugio Valenzuela, quien pertenecía al círculo de Melesio Morales. Posteriormente estudió

7 El esbozo biográfico de Guadalupe Olmedo que presento aquí está basado en información que me ha compartido la musicóloga Gisela Marrero, quien escribió apuntes biográficos de esta compositora para la plataforma digital de la Fonoteca Nacional denominada Musiteca. Con respecto a la biografía de María Garfias, se puede consultar el valioso libro, recién publicado, del musicólogo Fernando Carrasco (2018).

ESCENA. Revista de las artes, 2020, Vol. 79, Núm. 2 (enero-junio), pp.189-213 
Hacia un nuevo ideal femenino: el pianismo decimonónico de Guadalupe

Dossier Olmedo y María Garfias

de manera particular con Agustín Balderas y con el compositor Cenobio Paniagua, uno de los primeros mexicanos en componer una ópera bel cantista, Catalina de Guisa.

Debido a la partida de Cenobio Paniagua a la ciudad de Veracruz, Garfias decidió ponerse bajo la tutela de uno de sus alumnos más avanzados, Octaviano Valle, y a él dedica uno de sus dos caprichos de salón para piano, el denominado La campana del alba. El segundo, titulado Bacanal, fue dedicado al jurisconsulto Eulalio María Ortega, hermano del médico y compositor de la Marcha Zaragoza y la ópera Guatimotzin, Aniceto Ortega. Bajo la tutela de estos maestros compone y estrena, en 1862, sus primeras obras: Melodía, dedicada a su madre, y el Vals Gratitud en la colección El Repertorio, editada por Manuel Murguía. Además, estrena en el Teatro Nacional su Fantasía sobre temas de Martha, obra de un audaz virtuosismo, y la singular obra iiDios Salve a la Nación!!, escrita en homenaje al general Ignacio Zaragoza. Hasta la fecha hemos encontrado diecinueve obras de la autoría de Garfias, quince de ellas para piano, en un álbum encuadernado en pasta dura y adquirido por Jorge Martín Valencia en la ciudad de Puebla.

Se descubre en sus obras la cercanía política de Garfias con los liberales ${ }^{8}$, ya que, además de la obra iiDios Salve a la Nación!!, escrita ante la inminente caída de la Ciudad de México durante la segunda invasión francesa, encontramos la Marcha Republicana dedicada a Benito Juárez y la Danza Sé Feliz, dedicada al hijo de Porfirio Díaz. Como destacó Bitrán: "su obra no sólo contribuyó al arte musical, sino también a la construcción del discurso nacionalista surgido de la restauración de la República tras la caída del Segundo Imperio, en 1867" (Y. Bitrán, correo electrónico, 5 de enero de 2018).

De acuerdo a Carrasco, Garfias hizo su debut como pianista en el Teatro Nacional en 1862, con la Fantasía sobre temas de Lucía de Lammermoor de Emile Prudent; y además interpretó en 1866 y 1867 las Paráfrasis de concierto de Ernani y Rigoletto compuestas por Liszt, sobre temas de las óperas de Verdi. Sus últimas apariciones como compositora datan de 1867, año en que estrenó su Marcha republicana dedicada al presidente Benito Juárez, dirigiendo una orquesta con batuta desde el palco escénico del Gran Teatro Nacional; como ha señalado Carrasco: "quizá esto la convierta en la primera directora de orquesta quizá no sólo de México, sino de América" (Carrasco, F., comunicación personal, 30 de enero de 2018). El Correo de México del 21 de octubre de 1867 señalaba que:

8 El bisnieto de Garfias comentó en entrevista a Fernando Carrasco, que Garfias era juarista y que cuando Maximiliano llegó a México, la familia puso cortinas negras en sus ventanas en señal de luto. Porfirio Díaz fue testigo en el matrimonio de María Garfias.

9 ¡Dios salve a la Patria!, obra de Melesio Morales para coro, orquesta y banda de guerra, trató el mismo tema.

ESCENA. Revista de las artes, 2020, Vol. 79, Núm. 2 (enero-junio), pp. 189-213 
la señorita Garfias, discípula del maestro D. Octaviano Valle, artista inspirada y mexicana de todo corazón, contribuirá de una manera muy poderosa á dar al espectáculo un extraordinario interés con su magnífica MARCHA REPUBLICANA, que se tocará por la orquesta y una banda militar, y á telón alzado, y que dirigirá personalmente desde el palco escénico, haciendo con esto una éra nueva en los anales de la música, y abriendo el talento, sea cualquiera el sexo del individuo, nuevo campo para que se manifieste y desarrolle (El Correo de México, 21 de octubre de 1867, citado en Carrasco, 2018, p. 21).

Solo se ha encontrado un registro posterior, de 1868, cuando estrenó su Marcha Guerrera, dedicada a Porfirio Díaz. En ese mismo año se casó con el ingeniero Ignacio Garfias, con quien procreó dos hijos: Mario y Manuel, ambos fallecidos antes que ella. El escritor Juan de Dios Peza, autor del libro Tradiciones y leyendas mexicanas (junto con Vicente Riva Palacio), escribió una dedicatoria a María que reza así: "A la virtuosa Señora María Garfias de Garfias, a esa maga del piano que ha encubierto su gloria en las venturas de un hogar tranquilo" (Carrasco, 2018, p. 34). María Garfias falleció el 9 de marzo de 1918, a consecuencia de una pulmonía, y sus restos reposan en el Panteón Español.

En cuanto a Guadalupe Olmedo, el biógrafo Francisco Sosa publicó un breve retrato de la compositora intitulado "Señorita Guadalupe Olmedo", en su libro Los contemporáneos, datos para la biografía de algunos mexicanos distinguidos en las ciencias, en las letras y en las artes (1884), en el que Sosa incluye solamente a tres músicos: Julio Ituarte, Melesio Morales y Guadalupe Olmedo. Después de referir su nacimiento en Toluca el 12 de diciembre de 1853 [sic], Sosa inicia el perfil biográfico de la compositora:

La señorita Olmedo es una artista de las más aventajadas con que se honra la sociedad mexicana, y pertenece á una familia distinguida. Dedicóse por recreación á la música, sobresaliendo bien pronto como pianista de singular mérito. No conforme la niña con sus glorias de ejecutante quiso ser compositora y estudió con especial aprovechamiento los tratados de armonía, contrapunto é instrumentación, escritos por Mattei, Fenaroli, Eslava, Berlioz, Fetiz, Reicha, Pameron, etc., revisando á la vez las mejores partituras de los autores clásicos (Sosa, 1884, p. 115).

Sorprende esta amplia gama de autores que abarca todo un siglo de saberes musicales: el Partimenti, Basso numerato de Fenaroli, publicado ca. 1800 en Nápoles, que es un tratado de amplio alcance en el que además del conocimiento sistemático de la conducción de voces, Olmedo aprendió valiosos recursos contrapuntísticos que pudo reforzar con los tratados más recientes de Reicha, Fétis y Berlioz. Hija de una familia acomodada, Guadalupe comenzó sus estudios de piano a temprana edad y fueron sus maestros Cenobio Paniagua y Agustín Caballero (Pareyón, 2007). El interés y entusiasmo que la música despertó en la niña Olmedo la llevó a tener un alto nivel en la ejecución del piano y, gracias a sus profundos estudios musicales, se distinguió entre las demás jóvenes que tocaban el piano como aficionadas a la 
música. Su excelente formación musical le permitió a la señorita Olmedo ser aceptada como alumna en el Conservatorio de la Sociedad Filarmónica a los quince años (1870), donde realizó estudios de composición bajo la guía del maestro Melesio Morales, uno de los compositores de ópera más representativos de la segunda mitad del siglo XIX. Entre otras óperas, Morales fue autor de Ildegonda (1866), y la pianista realizó el arreglo a cuatro manos del Preludio y la Paráfrasis de la misma obra para piano solo.

Sosa añade otros detalles sobre los estudios de Guadalupe, ya que parece haber visto uno de sus cuadernos musicales, en los que llama la atención su dedicación en el abordaje de técnicas contrapuntísticas:

La serie de estudios prácticos ejecutados por la Srita. Olmedo, forma un álbum de más de doscientas páginas, en las que están expresadas, y con sus respectivos análisis, las diversas clases de contrapunto conocidas, y varias fugas á dos, tres y cuatro partes según el sistema indicado por Reicha (Sosa, 1884, pp. 116-117).

La joven Guadalupe realizó una destacada carrera musical en el Conservatorio de la Sociedad Filarmónica: en 1875 se graduó a los 19 años, siendo la primera compositora mexicana en recibirse en ese plantel. Para su examen final, Guadalupe presentó quince obras entre las que destacan el Quartetto Studio Classico Op. 14 y la Obertura Luisa Op. 15. Como se ha dicho, en las partituras de ambas obras se encuentra un comentario escrito a mano en tres idiomas (inglés, francés y español), del cual se transcribe un fragmento:

Guadalupe Olmedo, joven de 19 años, es una de las dilettanti más aventajadas con que se honra la Sociedad Mexicana.

En el examen de composición que la Srita Olmedo sustentó por voluntad de sus padres en el Conservatorio de Música de México (Nbre. de 75) después de un interrogatorio que dignamente sostuvo durante tres cuartos de hora y la resolución satisfactoria de varios problemas armónicos que el Jurado le preparó, presentó 15 composiciones de diversos géneros entre las cuales figuran las presentes, valiéndole el Quartetto y la Obertura (Op. 14 y 15) la aprobación clamorosa del jurado y la concesión extraordinaria pedida por este y acordada por la Junta Directiva de una Medalla de plata con las inscripciones siguientes:

$1 \mathrm{a}$

A la Srita Guadalupe Olmedo, primera compositora mexicana que ha escrito en el género clásico.

$2 \mathrm{a}$

La Junta Directiva de la Sociedad Filarmónica Mexicana.

1875

ESCENA. Revista de las artes, 2020, Vol. 79, Núm. 2 (enero-junio), pp. 189-213 
Diversas fuentes hemerográficas nos remiten a ocasiones de extravagancias pianísticas, como la ejecución de la Marcha sacra de la ópera El Profeta, arreglada para cuatro pianos y diez y seis manos y orquesta, ejecutada por ocho señoritas incluida Guadalupe Olmedo (Fiesta musical, 17 de marzo de 1873; El Siglo Diez y Nueve, p. 3.), y otras obras para dieciséis manos, como la transcripción de la propia Olmedo sobre temas de La Africana de Meyerbeer, Op. 13, para cuatro pianos y dieciséis manos, cuya partitura se encuentra en la Biblioteca del Conservatorio Nacional de México; el programa incluyó otra transcripción de Olmedo de la ópera Los Hugonotes, también para cuatro pianos y dieciséis manos, que en esa ocasión fue ejecutada por cuatro mujeres y cuatro hombres (Concierto, 8 de agosto de 1878, El Siglo Diez y Nueve, p. 2).

Sus obras se empezaron a publicar en Milán, Leipzig y México, y entre 1884 y 1886 colaboró en las revistas El Álbum Musical y la Revista Melódica, publicadas por la famosa editorial de música H. Nagel y Sucesores (Pareyón, 2007, p. 755). Cuatro años después de egresar del Conservatorio se le asignó la cátedra de piano para señoritas (1879). Posteriormente, a sus treinta años de edad, Guadalupe Olmedo se casó el 23 de noviembre de 1887 con su exmaestro (y ya colega en ese entonces) Melesio Morales.

Pero la felicidad de la vida marital no duró mucho para Guadalupe, ya que murió un año y medio después de su boda con Melesio, todavía muy joven, a los 32 años de edad,

Figura 2. Diploma otorgado a Guadalupe Olmedo por la Sociedad Filarmónica Mexicana (1875).

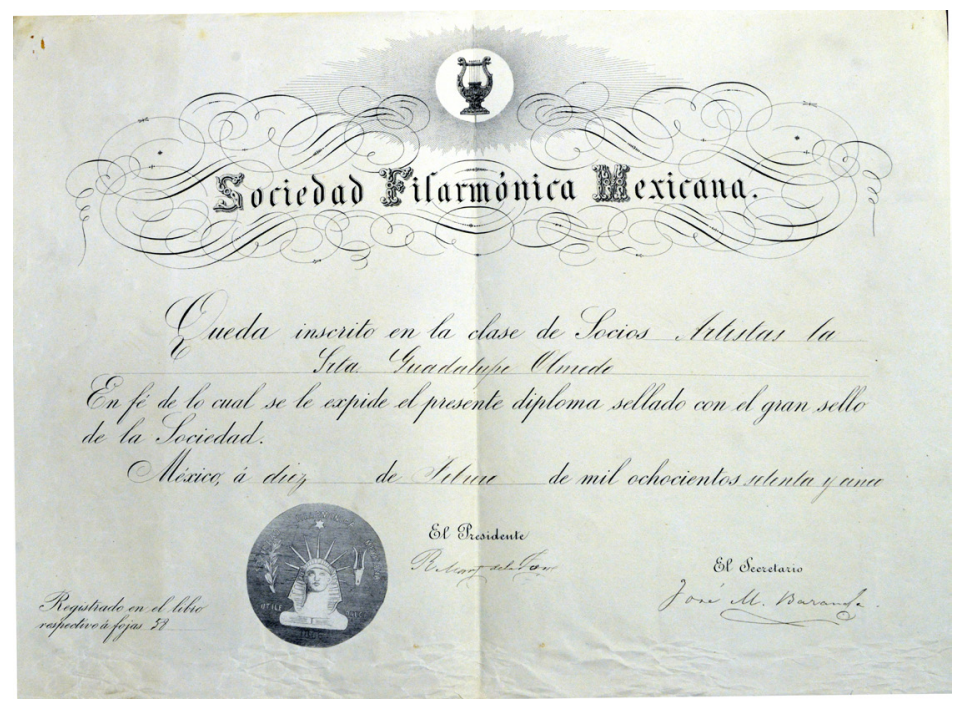

Fuente: Biblioteca del Conservatorio Nacional de Música de México (s.f.). el 11 de mayo de 1889. En el Fondo reservado de la Biblioteca del Conservatorio Nacional de Música se conserva una carta manuscrita de José Rivas, director en ese entonces del plantel, donde informa al personal docente sobre el fallecimiento de la apreciada maestra. Guadalupe Olmedo murió sin dejar descendencia, estando embarazada según el diario La Patria de México. Su tumba se localiza en el Panteón Español de la Ciudad de México, donde también fueron depositados los restos mortales de Melesio Morales y de su primera esposa, Ramona Landgrave (Pareyón, 2007, p. 693). 
Los méritos musicales de Guadalupe Olmedo y de María Garfias fueron reconocidos allende las fronteras de México; el Special Catalogue and Explanatory Notes de la Philadelphia International Exhibition, 1876, muestra que un grupo de sus obras, así como de las compositoras Ángela Peralta, Amalia Rocha y María Garfias, fueron seleccionadas para mostrarse en dicha Exposición Internacional (Centennial Exhibition Philadelphia, 1876). Posteriormente, en 1883, se incluyeron algunas obras tanto de Olmedo como de Garfias en el paquete de 391 piezas que envió México al gobierno de Venezuela en conmemoración del centenario del libertador Simón Bolívar.

\section{Comentarios sobre las obras}

Según consta en la partitura publicada de la obra, Melodía fue compuesta por Garfias a la edad de doce años y fue dedicada a su maestro de piano Agustín Balderas. Suponemos que esta obra obtuvo un reconocimiento importante por parte del público, ya que fue publicada por dos imprentas, la de J. Rivera e hijo, y por M. Murguía. Obra de tipo lírico, Melodía evidencia una estructura clara, equilibrada y lenguaje armónico sencillo, cumpliendo así con el tipo de música que Cumplido consideraba propio para las jóvenes mujeres estudiosas de la música.

Apenas un año después de la composición de Melodía, la Fantasía Martha de Garfias devela un lenguaje armónico mucho más complejo y su ejecución exige una sólida técnica pianística. Sin embargo, su Bacanal, subtitulada Capricho de salón, es una de las obras más logradas de la compositora por su ingeniosa concreción formal e interesante lenguaje armónico ${ }^{10}$. La compositora sin duda leyó la publicación Semanario de las Señoritas mejicanas. Educación científica moral y literaria del bello sexo, que señalaba en sus propósitos que "conforme a la máxima de Horacio lo útil se mezclará con lo grato, la diversión con las ciencias... [ya que] quien más sabe puede obrar mejor" (Semanario de las Señoritas mejicanas, p. VIII).

Sorprende la amenidad y el prolijo detalle con que algunos asuntos son tratados en el Semanario. En el caso de la música se mencionan, por ejemplo, los diferentes géneros -diatónico, cromático y armónico- de la música antigua en Grecia y se alude a importantes autores como Jean de Muris, Palestrina, entre otros. Con relación al tema de la Bacanal, en un capítulo dedicado a las máscaras, el Semanario de las señoritas mejicanas hace una descripción detallada de cómo

los bacantes se vestían con pieles de tigres y de las cabras que habían degollado, y disfrazados de este modo, marchaban en cuatro pies en las ceremonias á ejemplo de aquellos animales, teniendo el rostro cubierto con una máscara horro-

${ }^{10}$ Obra dedicada al Lic. Eulalio M. Ortega, hermano del compositor Aniceto Ortega

ESCENA. Revista de las artes, 2020, Vol. 79, Núm. 2 (enero-junio), pp. 189-213 
rosa, que procuraba imitar al animal de cuyos despojos iban vestidos... el uso de las máscaras era frecuente en las ceremonias religiosas y en las fiestas de sus falsas deidades; pero en las saturnales aun los esclavos que podían disfrutar de su libertad todo el tiempo que duraban (I.G., 1841, p. 235).

El texto, seguramente conocido por Garfias, inspiró una pieza de fantasía desbordada en la que diversas escenas musicales se suceden de manera contrastante. La obra lleva el subtítulo de Capricho, género que Rousseau definió en su Dictionnaire de Musique como "especie de música libre, en el cual el autor, sin sujetarse a propósito alguno, abre campo a su genio y se entrega al fuego de la composición" (Rousseau, 2007, p. 218). Rousseau distingue las diferencias entre el capricho y la fantasía de manera puntual:

el capricho es una colección de ideas singulares y disparates ordenados por una imaginación calenturienta y que incluso se puede componer con toda tranquilidad, mientras que la fantasía puede ser una pieza muy regular... que se inventa al tiempo que se ejecuta (Rousseau, 2007, p. 218).

Garfias establece en su Bacanal una estructura en la que aparecen cuatro temas diferentes, articulados a través de elementos tipo cadenza o transiciones de carácter libre sin compás. Comparando la obra temprana Melodía con Bacanal, se destaca en esta última una intensificación en la gama de recursos expresivos, la dinámica es rica en contrastes, sucediendo a fortísimos súbitos pianísimos. La libertad en el tiempo se obtiene a través de precipitatos, stringendos, triples fortísimos con passione seguidos de molto ritenutos, llegando hasta triples pianísimos smorzando y perdendosi, concreción sonora de libertad e intensidad vital de esta mascarada que culmina en un martellato con bravura que hace caso omiso de las exhortaciones de Cumplido a las señoritas de evitar "sonidos estrepitosos o la complicación de su ejecución" (citado en Bitrán, 2012, p. 76).

Sobresale el uso de la modulación a tonalidades lejanas a través del recurso de enarmonización, como, por ejemplo, de Re bemol mayor a La mayor, a través de la enarmonización de Re bemol = Do sostenido. Pero también es probable que la joven pianista haya abordado el tema de Baco debido a su contacto con la literatura latina, tan estudiada en México desde el período colonial. Las traducciones de la obra horaciana realizadas por Javier Burgos desde 1820 y publicadas por José Cuesta en Madrid en 1844 tuvieron difusión en el México decimonónico.

Especulo que Garfias pudo conocer la Oda XIX del libro segundo de Horacio, "Canción a Baco" y que esta pieza musical pudo impregnarse de la substancia poética de la oda horaciana. En mi trabajo interpretativo de esta obra me aventuro a pensar que el discurso musical "pinta" sonoramente algunas imágenes del poema; por ejemplo, el inicio de la obra de Garfias puede ser una representación de la escucha atenta de los sátiros y 
ninfas del canto de Baco "entre peñascos escarpados" plasmados sonoramente como una sucesión de arpegios de los compases 1 al 9. Posteriormente, la escritura musical abunda en exuberancia sonora y diversos contrastes tanto agógicos como dinámicos -stringendi, fff con passione, perdendosi- durante los compases 27 al 45, en los que podemos "escuchar" a las Bacantes: "que es permitido en arrebatos píos, cantar de las Bacantes los alaridos roncos, de vino fuentes y de leche ríos". La parte final de la Bacanal puede aludir al triunfo de Baco: "diestro solo en donaire, juego y danzas... adornado de cuerno refulgente, te vé manso el Cerbero" (Horacio, 1844, p. 469).

Por otro lado, la Marcha Republicana fue dedicada al presidente Benito Juárez y estrenada poco tiempo después del fusilamiento de Maximiliano de Habsburgo. La obra

Figura 3. Fragmento de la Bacanal de María Garfias

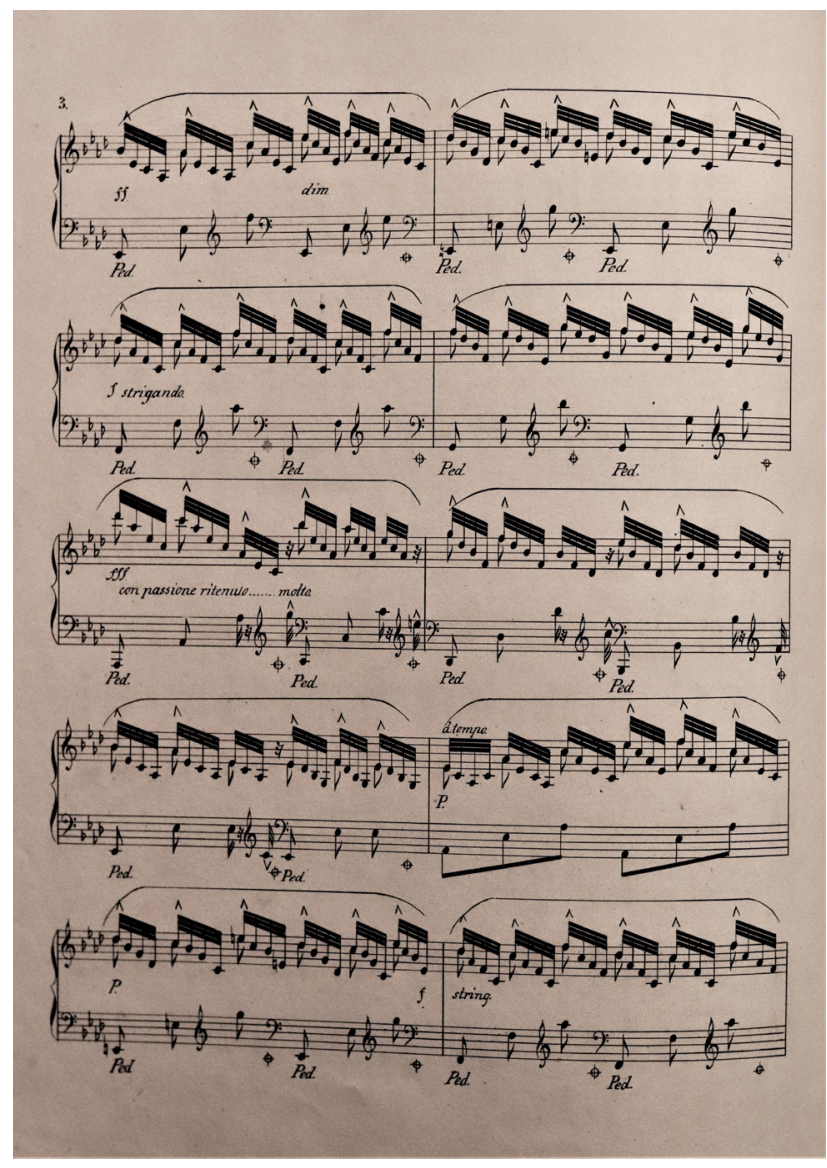

Fuente: Archivo personal del guitarrista Jorge Martín Valencia Rosas. refleja un ánimo patriótico restaurado ya queapenasveinteañosantesMéxicohabía perdido más de la mitad de su territorio en la guerra con los Estados Unidos de América. Al menos en esta ocasión, el invasor extranjero -apoyado por los conservadores - había sido derrotado y repelido ${ }^{11}$. La Marcha Republicana fue orquestada y dirigida desde el podio por la compositora, siendo éste el primer caso registrado de una mujer directora de orquesta en México. Inspiró esta obra a otras mexicanas más jóvenes a asumir una postura contestataria; por ejemplo, Laureana Wright, autora de La educación errónea de la mujer y medios prácticos para corregirla, que dedicó un Soneto a María Garfias con motivo del estreno de esta marcha. La versión orquestal está perdida, solamente existe la pianística en la que predominan notas dobles en ambas manos y octavas en todos los

${ }^{11}$ Se compusieron canciones populares celebrando la caída del Segundo Imperio. Adiós Mamá Carlota es un conocido ejemplo de este tipo de piezas. 
registros del instrumento que exigen, por momentos, una ejecución de bravura. Una vez más, Garfias expone material contrastante en las diversas partes de la obra, a un desbordado entusiasmo inicial se sucede un intenso lirismo que en continuo crescendo desemboca en el retorno al tema principal y una coda en la que se aprecian interesantes progresiones armónicas en las que se observan interesantes transformaciones de los grados IV y VI de La bemol mayor, el primero se presenta como menor (IV arm.) y el segundo descendido un semitono, como Fa bemol mayor.

Figura 4. Modulación enarmónica en la Bacanal de María Garfias

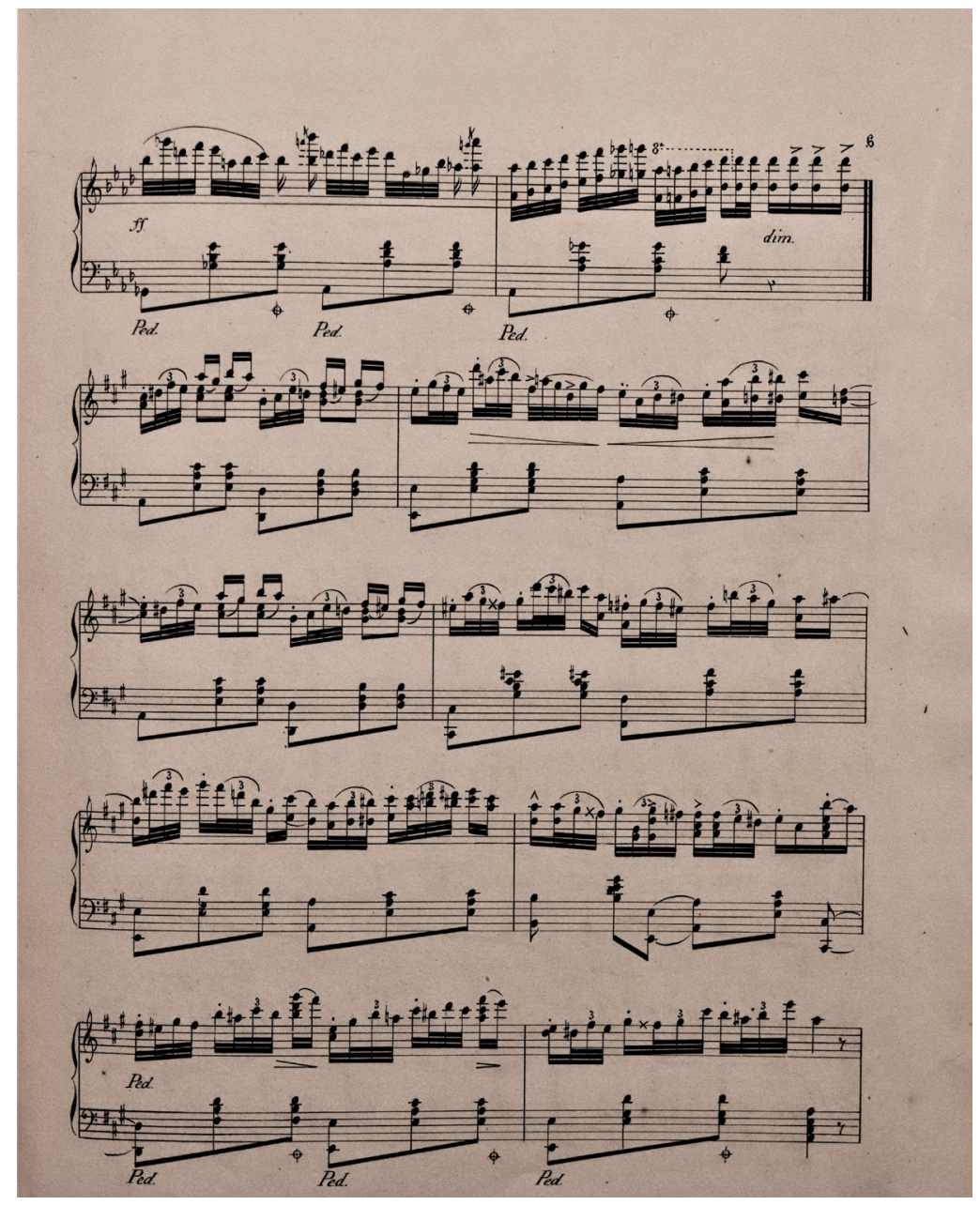

Fuente: Archivo personal del guitarrista Jorge Martín Valencia Rosas. 
Hacia un nuevo ideal femenino: el pianismo decimonónico de Guadalupe

Dossier

Olmedo y María Garfias

Figura 5. Final de la Marcha Republicana de María Garfias

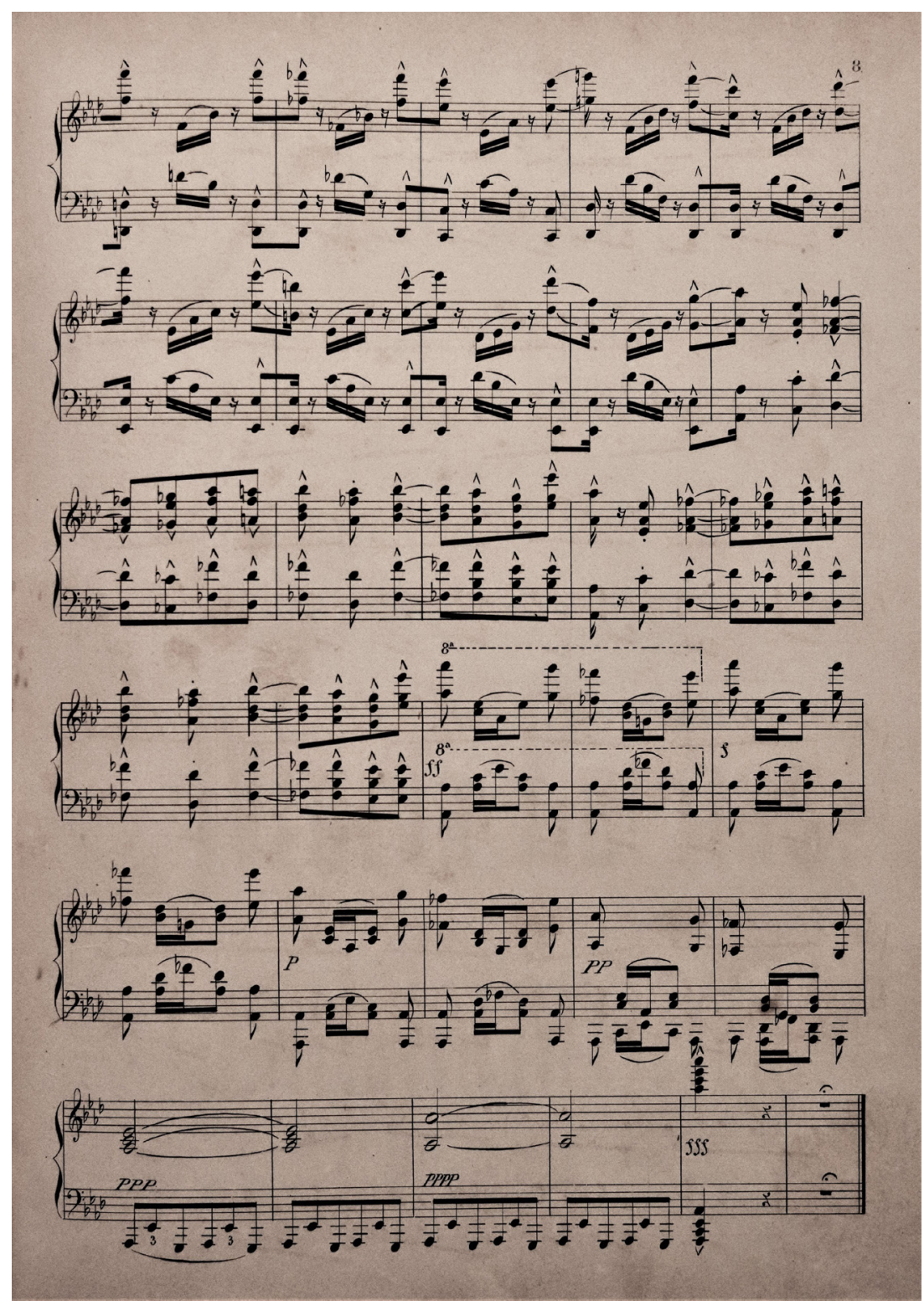

Fuente: Archivo personal del guitarrista Jorge Martín Valencia Rosas.

Con relación a las obras de Guadalupe Olmedo, creemos importante resaltar las opiniones de su primer biógrafo, Sosa, y que coinciden con Cumplido en cuanto a las cualidades y características deseables en la música compuesta para el "bello sexo". Más 
adelante veremos cómo Olmedo desarrolla un estilo más personal y, en definitiva, un pianismo de alta exigencia técnica y expresiva en sus últimas obras.

Nótase en la música de la Srita. Olmedo, esa plácida melancolía que retrata el carácter de los hijos de México, esa dulzura inefable que mana del sensible y delicado corazón de nuestras mujeres, esa apacible ternura de que se siente animado el artista, cuando, inspirado, externa en sus producciones la sensibilidad de su alma... en las piezas para piano se admira la elegancia con que están variados los temas, dispuestos bajo una forma que no desdeñarían Smith, Ketterer ó Goria. (Sosa, 1884, pp. 117-118).

En el cuerpo de obras de Olmedo encontramos algunas que fueron publicadas sin número de opus, y existen dos obras que comparten el Opus 1. El primero de ellos se conserva en manuscrito y lleva como título Caricia a mi madre. Nocturno para piano; se trata de una obra breve de 80 compases, de carácter monotemático, en los que la autora teje el discurso musical a través de un sencillo plan armónico que oscila entre las tonalidades de mi bemol mayor y la bemol mayor. Las frases regulares de 4 compases se expanden ocasionalmente a 6 presentando algunas ornamentaciones y fiorituras. La escritura es clara, nítida y corresponde a la descripción que Sosa hiciera de Olmedo: "la modestia, compañera inseparable del verdadero mérito, es una de las más hermosas cualidades que adornan á la Srita. Olmedo, modestia que llega hasta la humildad" (Sosa, 1884, p. 119).

Por otro lado, el segundo opus 1 fue publicado en Milán, y también es una obra tipo nocturno que lleva por título: Luz, pensamiento poético. Observamos aquí el uso de los mismos recursos compositivos: un discurso musical basado en un solo tema que se presenta en dos tonalidades: re bemol mayor y sol bemol mayor -la tónica y la subdomi-

Figura 6. Nocturno Caricia a mi madre, inicio de la obra

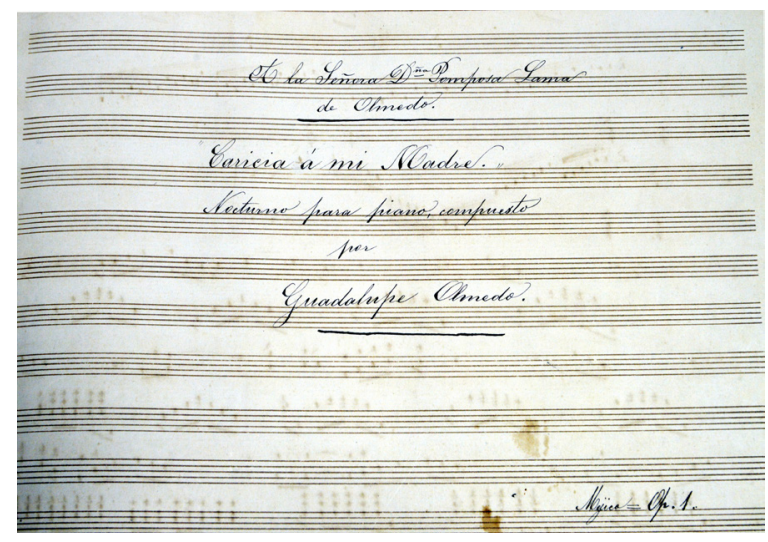

Fuente: Archivo Histórico de la Biblioteca del Conservatorio Nacional de Música de México. nante, como en Caricia a mi madre-, una corta introducción tipo cadenza, y una constante elaboración ornamental en la que las dominantes auxiliares crean diversas intensidades expresivas acentuadas a través del animando y algunos cromatismos en dinámica forte.

Mayor ímpetu virtuoso encontramos en su Obertura Luisa Op.8 para piano y que posteriormente orquestó publicándolo como Op.15. Una vez más encontramos el lenguaje armónico libre de pretensiones, aunque con mayores recursos: el IV armónico (menor), así como algunos ocasionales cromatismos que no alteran el claro plan armónico 
Hacia un nuevo ideal femenino: el pianismo decimonónico de Guadalupe

Dossier Olmedo y María Garfias

con modulaciones siempre a tonalidades vecinas. Si bien toda la obra se desarrolla a partir de un simple motivo inicial que incluye la cuarta justa y un segmento de escala descendente, la obra oscila entre diversos tempi: al allegreto brillante de la introducción inicial se suceden tempi en los que se acelera gradual y explosivamente el movimiento: moderato gentile, vivace, presto y prestissimo, con lo que se compensa la economía de recursos armónicos. La escritura pianística, sin embargo, requiere una solvencia técnica importante, ya que abundan los pasajes de octavas, notas dobles y ágiles dieciseisavos. En el único ejemplar que hemos encontrado faltan dos páginas que pudimos reconstruir gracias a que en el Archivo Histórico de la Biblioteca del Conservatorio Nacional se conserva la partitura orquestal completa, de la que realicé una transcripción del material faltante, respetando la textura que utilizó la autora en la versión pianística.

Se destaca entre las obras de Guadalupe Olmedo su Paráfrasis de Ildegonda, obra que revela un alto nivel de virtuosismo en la que encontramos pasajes de bravura, arpegios complejos, notas dobles, saltos que abarcan la totalidad de los registros del piano, una técnica pianística depurada en el contexto de un discurso poético-musical perfectamente hilvanado, comparable con el de compositores contemporáneos destacados de México, como Ricardo Castro y el propio Morales.

El tema de la ópera Ildegonda es una leyenda medieval que tiene lugar en el siglo XII en Milán. En el argumento, Ildegonda, hija de Rolando, señor de Gualderano, se rebela ante la perspectiva de aceptar un casamiento arreglado que unificaría a Lombardía. Al conocer su hermano que Ildegonda ama a Rizzardo, joven plebeyo, le tiende una emboscada a éste, pero muere a manos de su rival. Rizzardo huye e Ildegonda es confinada a un convento. Con la certeza de que Rizzardo va a morir, Ildegonda se vuelve loca. Rolando, viendo a su hija agonizante, perdona a Rizzardo. Ildegonda se acuerda de la maldición de su padre y cuando llega su amante, ella muere.

El día 17 de marzo de 1873, Olmedo tocó en el mismo programa la Paráfrasis de Rigoletto de Liszt y su Paráfrasis de Ildegonda. La selección de temas enfatiza el contenido dramático de la obra; Olmedo inicia su paráfrasis con el "tema de la conjura", momento en que los caballeros de Rolando planean la muerte de Rizzardo. Los temas elegidos por la compositora están reformulados en un lenguaje plenamente pianístico, a través de fulgurantes figuras ya en dieciseisavos, ya en rápidos acordes y arpegios que nos remiten al conocimiento y familiaridad que desarrolló Olmedo sobre la obra de Liszt. En su Paráfrasis, Olmedo se aparta de las tonalidades originales estableciendo un planteamiento armónico osado en el que se recurre a la enarmonía para modular a tonalidades lejanas, como en el tema del compromiso obligado de lldegonda.

ESCENA. Revista de las artes, 2020, Vol. 79, Núm. 2 (enero-junio), pp. 189-213 
Figura 7. Obertura Luisa para piano, primera página

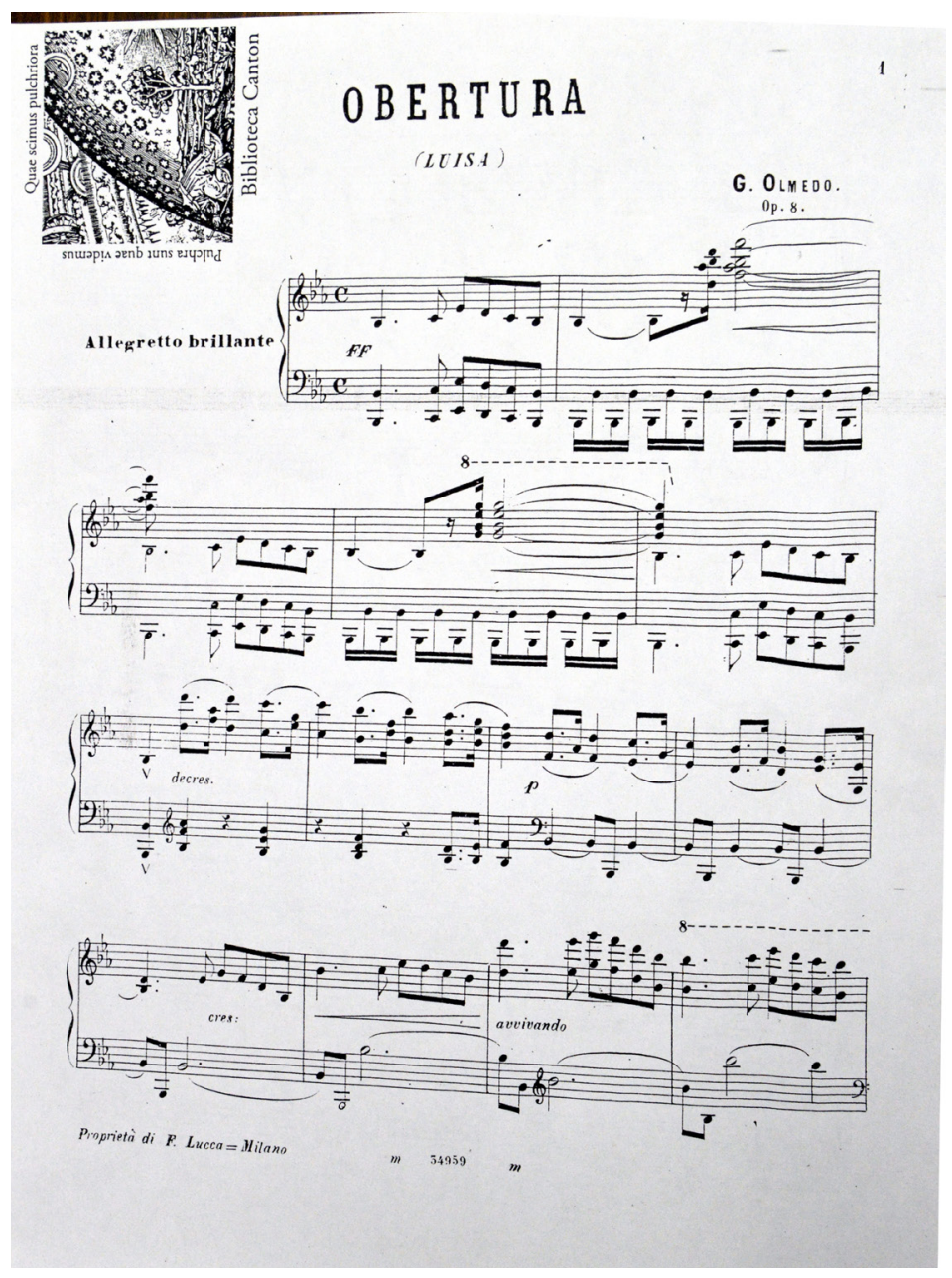

Fuente: Archivo Histórico de la Biblioteca del Conservatorio Nacional de Música de México.
El plan tonal de la obra, transita audazmente por diversas tonalidades: Fa menor, Re bemol mayor, Sol bemol mayor, Re bemol mayor $=$ Do sostenido mayor, Fa sostenido menor, Mi menor, $\mathrm{Mi}$ mayor.

El final de la pieza, en $\mathrm{Mi}$ menor y después Mi mayor, cierra un osado planteamiento armónico que nos dirige a una especie de abismo en la conclusión descendente a Mi menor, posteriormente mayor, que descarta toda posibilidad de regreso a la tonalidad inicial, fa menor.

Nos encontramos muy alejados de la recomendación de Cumplido en la Revista de Señoritas: "evitar toda pretensión y actuar con suprema simplicidad; tocando con claridad, limpieza y expresión... la música es valiosa por las impresiones que realiza en nuestra alma, no por sus estrepitosos sonidos o la complicación de su ejecución" (citado en Bitrán, 2012, p. 76).

\section{Conclusiones}

Las composiciones de Guadalupe Olmedo y María Garfias revelan una evolución en el pensamiento compositivo, desde las obras pensadas para un espacio hogareño hasta aquellas de alto nivel de virtuosismo que sólo pueden ser ejecutadas por profesionales del instrumento. Observamos un empoderamiento en la forma de abarcar, atrapar y dominar la totalidad de registros del piano, así como en la exploración de todas las posibilidades del lenguaje tonal incluyendo algunos recursos de tipo cromático. 
Podemos decir que a través de los audaces recursos compositivos en las obras comentadas en el presente artículo, nuestras compositoras asumieron una voz alejada de lo considerado como ideal femenino -según lo convencionalmente aceptado como tal en el pensamiento del México del siglo XIX- y con ello contribuyeron a contestar y transgredir el territorio considerado como propio de lo masculino, coadyuvando así en los profundos cambios culturales que se dieron en la joven nación mexicana, para los cuales las mujeres realizaron destacadas aportaciones en los campos de las artes, la educación y la ciencia.

Figura 8. Obertura Luisa, portada de la partitura orquestal

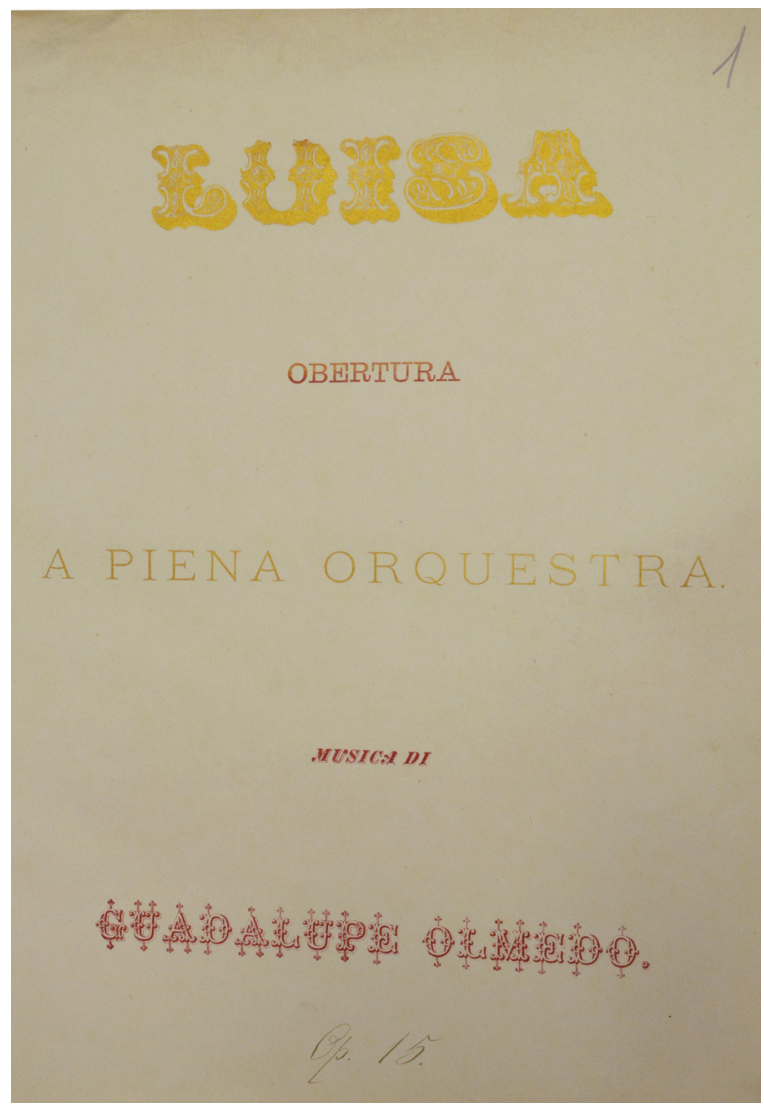

Fuente: Archivo Histórico de la Biblioteca del Conservatorio Nacional de Música de México.
Figura 9. Página inicial de la Paráfrasis de IIdegonda de Guadalupe Olmedo

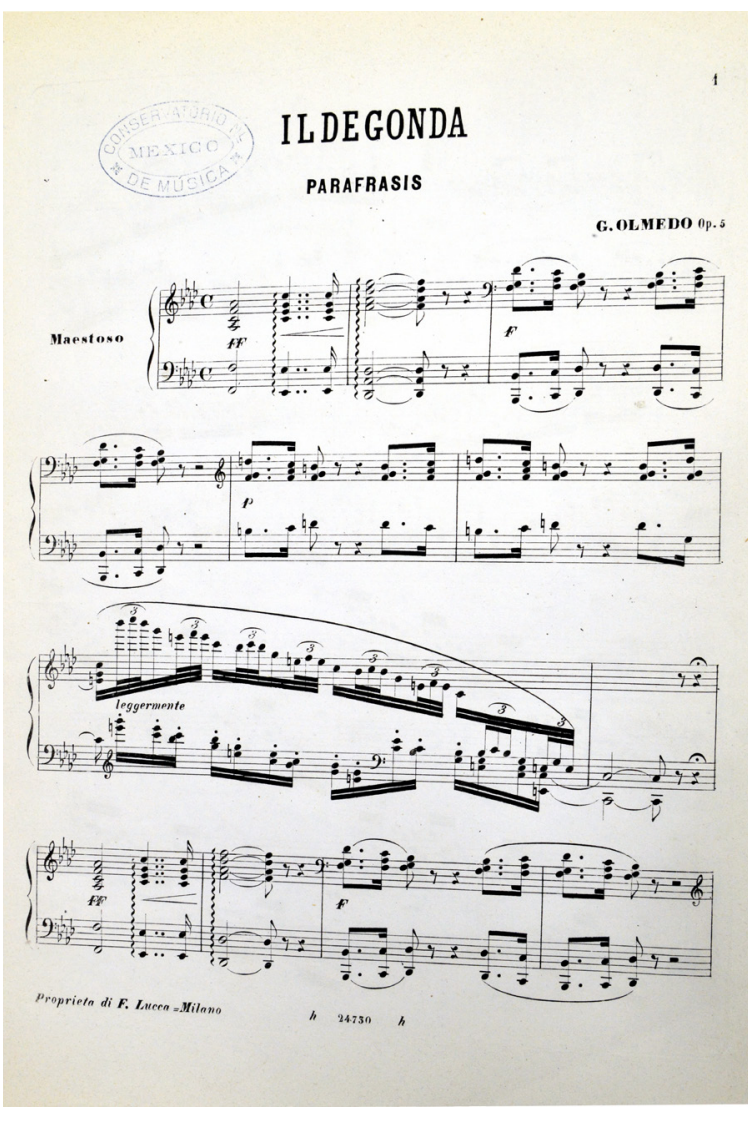

Fuente: Archivo Histórico de la Biblioteca del Conservatorio Nacional de Música de México.

El audaz plan compositivo de las obras, así como el exuberante pianismo virtuoso, simboliza de alguna manera el desarrollo de estas compositoras, quienes, de la misma manera que lldegonda, se rebelaron ante un orden impuesto por su entorno social y cultural. 
Figura 10. Modulación enarmónica en la Paráfrasis de lldegonda de Guadalupe Olmedo

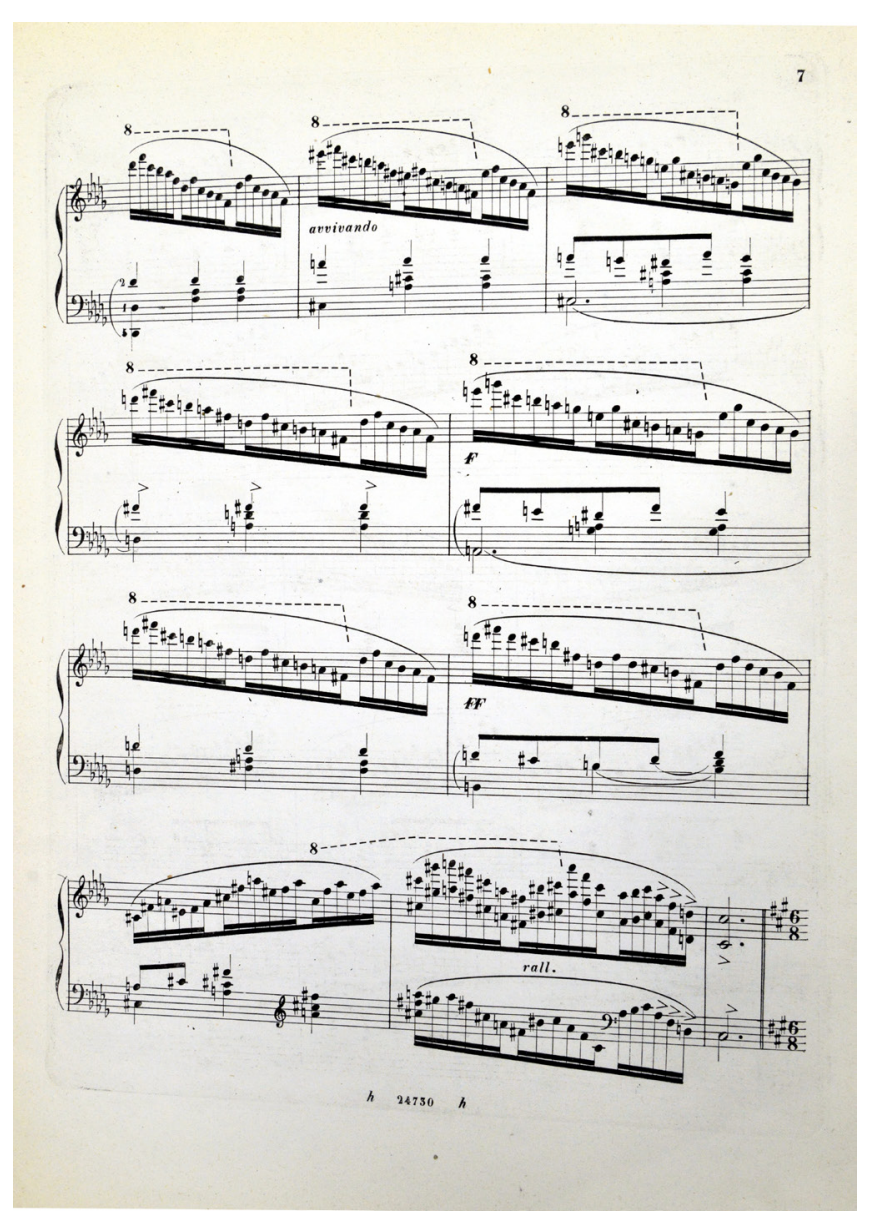

Figura 11. Final de la Paráfrasis de Ildegonda de Guadalupe Olmedo

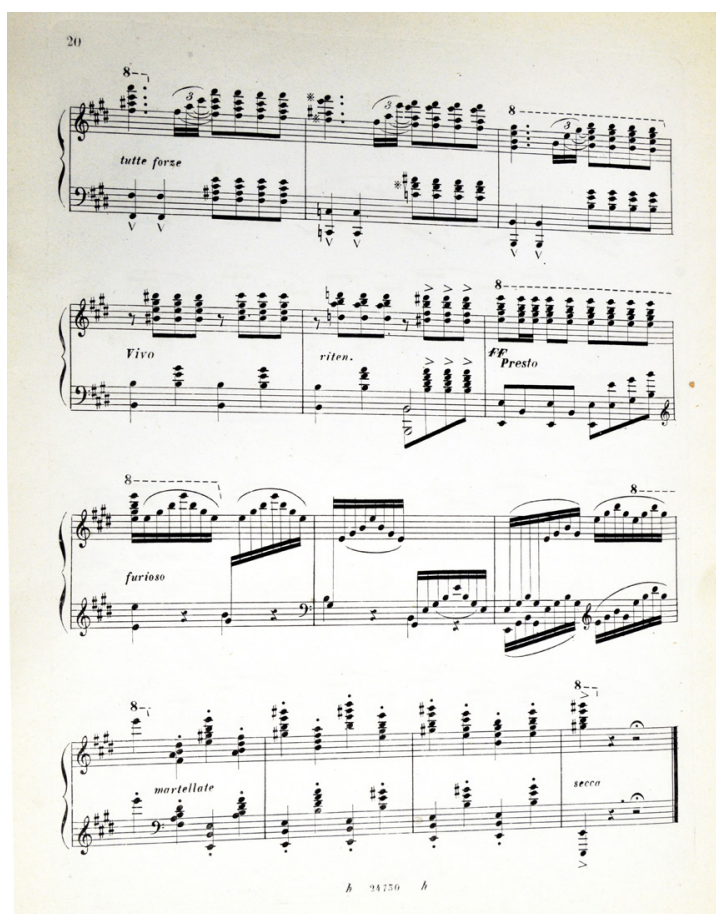

Fuente: Archivo Histórico de la Biblioteca del Conservatorio Nacional de Música de México.

Fuente: Archivo Histórico de la Biblioteca del Conservatorio Nacional de Música de México.

Las pocas grabaciones que se han hecho de sus obras y el desconocimiento de las mismas, que aún persiste en México, hacen deseable y necesario que los intérpretes se decidan a estudiar y grabar las obras de estas olvidadas compositoras mexicanas del Romanticismo mexicano, a quienes apenas empezamos a descubrir, apreciar y conocer. 
Hacia un nuevo ideal femenino: el pianismo decimonónico de Guadalupe

Dossier

Olmedo y María Garfias

\section{Referencias}

Aguirre Loera, M.E. (2002). Una invención del siglo XIX: La escuela primaria (17801890). En L.E. Galván Lafarga (Coord.). Diccionario de la educación en México. México: Universidad Nacional Autónoma de México. Recuperado de http://biblioweb. tic.unam.mx/diccionario/htm/articulos/sec_16.htm

Biblioteca del Conservatorio Nacional de Música de México. (s.f.). Archivo Histórico, cajas 156 y 120, registro 2337; caja 156, obra 3558 y registro 2336; caja 120, obra 2495.

Bitrán, Y. (2012). Musical Women and Identity-building in Early Independent Mexico (1821-1854) (tesis doctoral). Universidad de Londres, Londres.

Carrasco, F. (2018). María Garfias (1849-1918): Una fugaz presencia en la música mexicana decimonónica. Recuperado de https://musicologiacasera.files. wordpress.com/2018/04/marc3ada-garfias-1849-1918-una-fugaz-presencia-dela-mc3basica.pdf

Centennial Exhibition Philadelphia. (1876). Philadelphia International Exhibition, 1876, Mexican Section: Special catalogue and explanatory notes. Philadelphia: Dan F. Gillin.

El Siglo Diez y Nueve. (1873). México: Imp. de Ignacio Cumplido.

Horacio Flaco, Quinto. (1844). Oda XIX (Traductor Lista, A.). En Búrgos, Javier de (ed.), Las poesías de Horacio traducidas en versos castellanos, 2a. ed., tomo I (pp. 466469). Madrid: Librería de D. José Cuesta. Recuperado de https://bit.ly/30apZsn

I.G. (1841). Máscaras. Semanario de las Señoritas mejicanas, pp. 233-240. México: Imp. de Vicente G. Torres.

Juana Inés de la Cruz, Sor. (1951). Romance que escribe Sor Juana a la condesa de Paredes. En: Sor Juana Inés de la Cruz. Obras completas 1. Lírica personal. México: Fondo de Cultura Económica.

Morales, M. (1994). Julián Carrillo. En Melesio Morales. Labor periodística. México: CENIDIM

Morales, M. (febrero de 1906). Reseña que leyó a sus amigos el maestro Melesio Morales en la celebración de sus bodas de oro y del cuadragésimo aniversario de la fundación del Conservatorio de Música. El Tiempo.

Pareyón, G. (2007). Diccionario enciclopédico de música en México. México: Universidad Panamericana.

Pulido, E. (1991). La mujer mexicana en la música. Heterofonía III, (104-105), 6-51.

Rousseau, J. (2007). Diccionario de música. Madrid: Akal.

ESCENA. Revista de las artes, 2020, Vol. 79, Núm. 2 (enero-junio), pp. 189-213 
Semanario de las Señoritas mejicanas. (1841). México: Imp. de Vicente G. Torres.

Sosa, Francisco. (1884). Señorita Guadalupe Olmedo. En Los contemporáneos. Datos para la biografía de algunos mexicanos distinguidos en las ciencias, en las letras y en las artes, tomo primero. México: Imprenta de Gonzalo A. Esteva, pp. 11 